\title{
CPO and kinematic analysis of the Bitou S-tectonites (Central Cameroon shear zone): AMS and EBSD investigations
}

\author{
B E Bella Nke ${ }^{1,2,3}$, T Nuanko ${ }^{1,4, *}$ and J TChakounte ${ }^{4,5}$ \\ ${ }^{1}$ Laboratory of Environmental Geology, Department of Earth Sciences, University of Dschang, Dschang, Cameroon. \\ ${ }^{2}$ Department of Earth Sciences, Faculty of Sciences, University of Maroua, Maroua, Cameroon. \\ ${ }^{3}$ Department of Geology and Geophysics, Indian Institute of Technology Kharagpur, Kharagpur 721 302, India. \\ ${ }^{4}$ Ministry of Scientific Research and Innovation, DPSP/CCAR, Yaoundé, Cameroon. \\ ${ }^{5}$ Department of Earth Sciences, Faculty of Sciences, University of Yaoundé 1, Yaoundé, Cameroon. \\ *Corresponding author.e-mail: tnjanko@gmail.com
}

MS received 9 August 2018; revised 7 June 2019; accepted 19 June 2019

The development of foliation is not always associated with mineral stretching lineation in deformed rocks. Sometimes, S-tectonites only display foliation with no mineral stretching lineation, and it becomes a real challenge to perform kinematic analysis, i.e., to define the $X Z$ section of the ellipsoid. In this study, we present in a portion of the Central Cameroon Shear Zone (CCSZ) (the Bitou biotite gneiss mylonite), the usefulness of anisotropy of magnetic susceptibility (AMS) studies to identify the three principal axes of the AMS ellipsoid $\left(K_{1} \leq K_{2} \leq K_{3}\right.$ ), equivalents respectively to the principal axes of the strain ellipsoid $(X \leq Y \leq Z)$. The $K_{1} K_{3}$ plane of the AMS ellipsoid is equivalent to the $X Z$ section of the strain ellipsoid. The fabrics developed in the studied mylonitised biotite gneiss strike ENE-WSW to E-W with steep dips for the mylonitic and magnetic foliations and moderate plunges for the magnetic lineation. The rock is paramagnetic. The AMS ellipsoids are mostly of oblate shape, while the quartz $c$-axis pattern is typical of non-coaxial flow. This implies that deformation partitioning took place during mylonitisation. Quartz crystallographic preferred orientation (CPO) measured using electron backscatter diffraction reveals the activation of prism $<\mathrm{a}>$ slip, implying that the mylonitisation occurs under moderate temperature conditions $\left(450^{\circ} \mathrm{C}<T<550^{\circ} \mathrm{C}\right)$. Microstructures observed in the $K_{1} K_{3}$ section of the AMS ellipsoid and $\mathrm{CPO}$ of the quartz $c$-axis indicate sinistral top-to-SW sense of shear. These results support the shear senses of movement that earlier studies in the CCSZ have emphasised and are assumed to be related to the early syn- $\mathrm{D}_{2}$ and $\mathrm{D}_{3}$ events of the Pan-African tectonic dated at ca. 613-585 Ma.

Keywords. Mylonites; microstructures; AMS; CPO; shear zone; Cameroon.

\section{Introduction}

Previous research studies (e.g., Hrouda 1982; Bouchez 1997; Borradaile and Jackson 2004; Mamtani and Greiling 2005; Sen and Mamtani 2006) have demonstrated that an anisotropy of magnetic susceptibility (AMS) technique is an Published online: 24 August 2019 effective tool for petrofabric analysis. This technique has been used to detect any weak deformation event which is not observed at the outcrop scale (Mamtani et al. 1999; Tomezzoli et al. 2003; Raposo and Gastal 2009; Mamtani and Sengupta 2010; Njanko et al. 2010; Bella Nké et al. 2018). However, according to Bikramaditya Singh 
et al. (2017), the magnetic fabric of polydeformed mylonitic gneiss can be difficult to correlate with any corresponding mesoscopic fabric and other studies have shown that for granitic or gneissic deformed rocks, magnetic fabric may correspond to some fabric developed during a late stage of deformation (Ono et al. 2010). This can permit the identification of the orientations of the principal axes $(X, Y, Z)$ of finite strain to which the rock was subjected (Borradaile 1988).

Numerous studies in structural geology require kinematic analysis that involves the determination of the sense of shear using field observations, microstructures or crystallographic-preferred orientation (CPO) measured using scanning electron microscope-electron backscatter diffraction (SEMEBSD). Such investigation must be performed on sections cut parallel to the mineral stretching lineation and perpendicular to the foliation plane (i.e., $X Z$ section of the strain ellipsoid; Passchier and Trouw 2005). It is known that the $X Y$ plane of the strain ellipsoid represents the foliation plane in deformed rocks. The $X$-direction of the strain ellipsoid sometimes defines the mineral stretching lineation developed on the foliation plane and indicates the direction of tectonic transport. This implies that, in deformed rocks, the section parallel to the mineral stretching lineation and perpendicular to the foliation plane represents the $X Z$ section of the strain ellipsoid (figure 1), which is the reference frame required for kinematic analysis
(Bouchez 1997; Renjith et al. 2016). This is also the reference frame in which CPO is generally measured and then plotted on lower hemisphere equal area projection. The horizontal direction (dashed lines in figure 1) corresponds to the $X Y$ plane of the strain ellipsoid, where $Y$ is the centre and $X$, the mineral stretching lineation lies on the circumference (Passchier and Trouw 2005). This means that only deformed rocks that have developed foliation as well as visible mineral stretching lineation (known as LS-tectonites) can be used for kinematic analysis. However, in the field, all deformed rocks do not develop foliation as well as visible mineral stretching lineation; such rocks are referred to as S-tectonites. The absence of visible mineral stretching lineation may be linked to the dominance of flattening component during the rock deformation. Classical methods of structural analysis preclude kinematic studies in such rocks. According to Tarling and Hrouda (1993), Mondou et al. (2012), Parsons et al. (2016) and Bella Nké et al. (2018), the AMS method provides rapid information on the petrofabric of such deformed rocks and AMS orientation data $\left(K_{1}, K_{2}\right.$ and $\left.K_{3}\right)$ are used to determine the orientation of $X, Y$ and $Z$ axes of the strain ellipsoid.

According to Tarling and Hrouda (1993), Canon-Tapia (1994) and Parsons et al. (2016), the magnetic susceptibility $(K)$ defines the ratio between magnitudes of an externally applied magnetic field and an induced-magnetic field

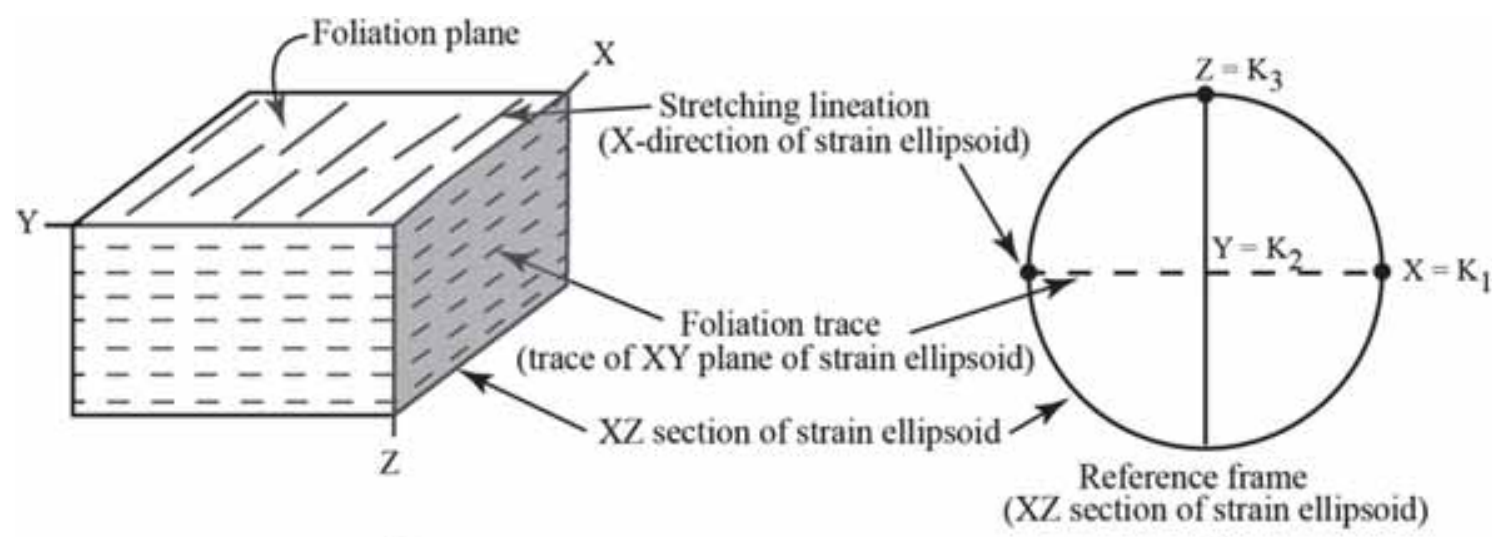

(a)

(b)

Figure 1. (a) Schematic block diagram indicating the mineral stretching lineation on the foliation plane (from Mamtani et al. 2017; Goswami et al. 2018). $X, Y$ and $Z$ represent the three principal axes of the strain ellipsoid with $X>Y>Z$. Dashed lines represent the trace of the foliation plane $(=X Y$ plane of the strain ellipsoid). Mineral stretching lineation marks the $X$-direction of the strain ellipsoid. Shaded face of the block diagram represents the $X Z$ section of the strain ellipsoid, which is a critical reference frame for kinematic studies and (b) pole figures (lower hemisphere equal area) of quartz crystallographic data (EBSD analysis) showing the reference frame that highlights the data plotted on the $K_{1} K_{3}$ plane (=XZ plane of the strain ellipsoid). The horizontal dashed line represents the trace of the foliation plane. 
strain. Magnetic susceptibility in most rocks is anisotropic, i.e., it changes with the direction of the induced field with respect to the rock. This directional variation of the magnetic susceptibility of samples is visualised as the AMS ellipsoid, with three mutually perpendicular principal axes: $K_{1 \text { - }}$ $=K_{\max }, K_{2}=K_{\text {int }}$ and $K_{3}=K_{\min }$, along which the magnetic susceptibility has the eigenvalues $K_{1} \geq K_{2} \geq K_{3}$. The magnetic foliation plane is defined by the $K_{1} K_{2}$ plane, whereas $K_{3}$ is its pole. $K_{1}$ is the magnetic lineation. These principal directions are used to evaluate the magnitude of various parameters: the mean magnetic susceptibility $\left(K_{\mathrm{m}}\right)$, the magnitude of the planar anisotropy $(F)$ and that of the linear anisotropy $(L)$, the degree of magnetic anisotropy $\left(P_{\mathrm{j}}\right)$ and the shape parameter $\left(T_{\mathrm{j}}\right) . P_{\mathrm{j}}$ defines the fabric intensity through the measure of the eccentricity of the AMS ellipsoid and $T_{\mathrm{j}}$ gives the shape of the AMS ellipsoid $\left(T_{\mathrm{j}}<0\right.$ for prolate shaped fabric and $T_{\mathrm{j}}>0$ for oblate shaped fabric).

According to Hanmer and Passchier (1991) and Passchier and Trouw (2005), mylonites or tectonites are defined as foliated and usually lineated rocks, occurring in high-strain zones, that show evidence of strong ductile deformation and normally contain fabric elements with monoclinic shape symmetry. Tectonites dominated by planar shaped fabrics are known as S-tectonites, while those dominated by linear shaped fabrics are L-tectonites. In tectonites, $K_{1}, K_{2}$ and $K_{3}$ orientations have been equated with the three principal axes of the strain ellipsoid, $X \geq Y \geq Z$ (Tarling and Hrouda 1993). S-tectonites then lack visible mineral stretching lineation and, according to Mamtani et al. (2017) and Bella Nké et al. (2018) among others, AMS measurements can help to identify orientations of the three principal axes of the strain ellipsoid and kinematic analysis can then be conducted on S-tectonites. S-tectonites have been described in many shear zones within the Pan-African Fold Belt of Central Africa in Cameroon where the most famous is the Central Cameroon Shear Zone (CCSZ; figure 2). In the present work, we sampled the biotite gneiss mylonite in the Bitou area, part of the Foumban-Bankim shear zone (figure 3), to highlight the usefulness of AMS and CPO data for structural and kinematic characterisations of S-tectonites within the CCSZ. Petrological, mineralogical and isotopic data of the study area have been provided (see Njonfang et al. 1998, 2006).

\section{Regional setting}

In the Central African Fold Belt (CAFB) in Cameroon, Ngako and Njonfang (2011) recently identified three successive tectonic events (i) crustal thickening (ca. 630-620 Ma) including the $D_{1}-D_{2}$ deformations; (ii) left lateral wrench movement (613-585 Ma) and (iii) right lateral wrench movement (ca. 585-540 Ma). This later event includes the CCSZ. The CCSZ is a ductile structure oriented $\mathrm{N} 70^{\circ} \mathrm{E}$ that has been considered as the NE prolongation of one of the major Brasiliano shear zones of the Borborema Province in Brazil, either the Patos shear zone (Caby et al. 1991) or the Pernambuco shear zone (Brito Neves et al. 2002; Cordani et al. 2003). This main shear zone goes through the Central African Republic (figure 2a) and extends to South Sudan. According to Ngako et al. (2003) and Njanko et al. (2006), the CCSZ system defines a fan geometry comprising the Adamawa shear zone (Njanko et al. 2006) and other anastomosed $\mathrm{N} 30^{\circ}-\mathrm{N} 40^{\circ} \mathrm{E}$ and $\mathrm{N}-\mathrm{S}$ shear zones.

According to Ngako et al. (2003, 2008) and Njonfang et al. (2008), the mylonitisation of the CCSZ system occurs as the result of a complex structural evolution marked by an early syn- $\mathrm{D}_{2}$ sinistral shear event in which the ensuing elements have been later obliterated by a syn- $\mathrm{D}_{3}$ dextral shear event (also see Tcheumenak Kouémo et al. 2014).

The Foumban-Bankim shear zone (figure 3; Njonfang et al. 2006, 2008), part of the CCSZ, reveals a complex strain geometry dominated by two different directions of mylonitic foliation: (i) the $\mathrm{N} 40^{\circ} \mathrm{E}$ direction in the Tikar plain, where the study area is located and (ii) the $\mathrm{N} 60^{\circ} \mathrm{E}$ to $\mathrm{N} 70^{\circ} \mathrm{E}$ direction to the SW and NE of the Tikar plain, defining a large scale S-shaped mylonitic band at the transition zone between two en-echelon segments, known as the Foumban shear zone (FSZ) to the SW and Adamawa shear zone (ASZ) to the NE.

\section{Methodology: AMS and EBSD analysis}

The present study applied the AMS method on oriented sample cores from eight stations of biotite gneiss mylonite in the Bitou area. AMS measurements were performed on multiple cylindrical cores of $25.4 \mathrm{~mm}$ diameter and $22 \mathrm{~mm}$ height drilled from oriented block samples using the KLY-4S 


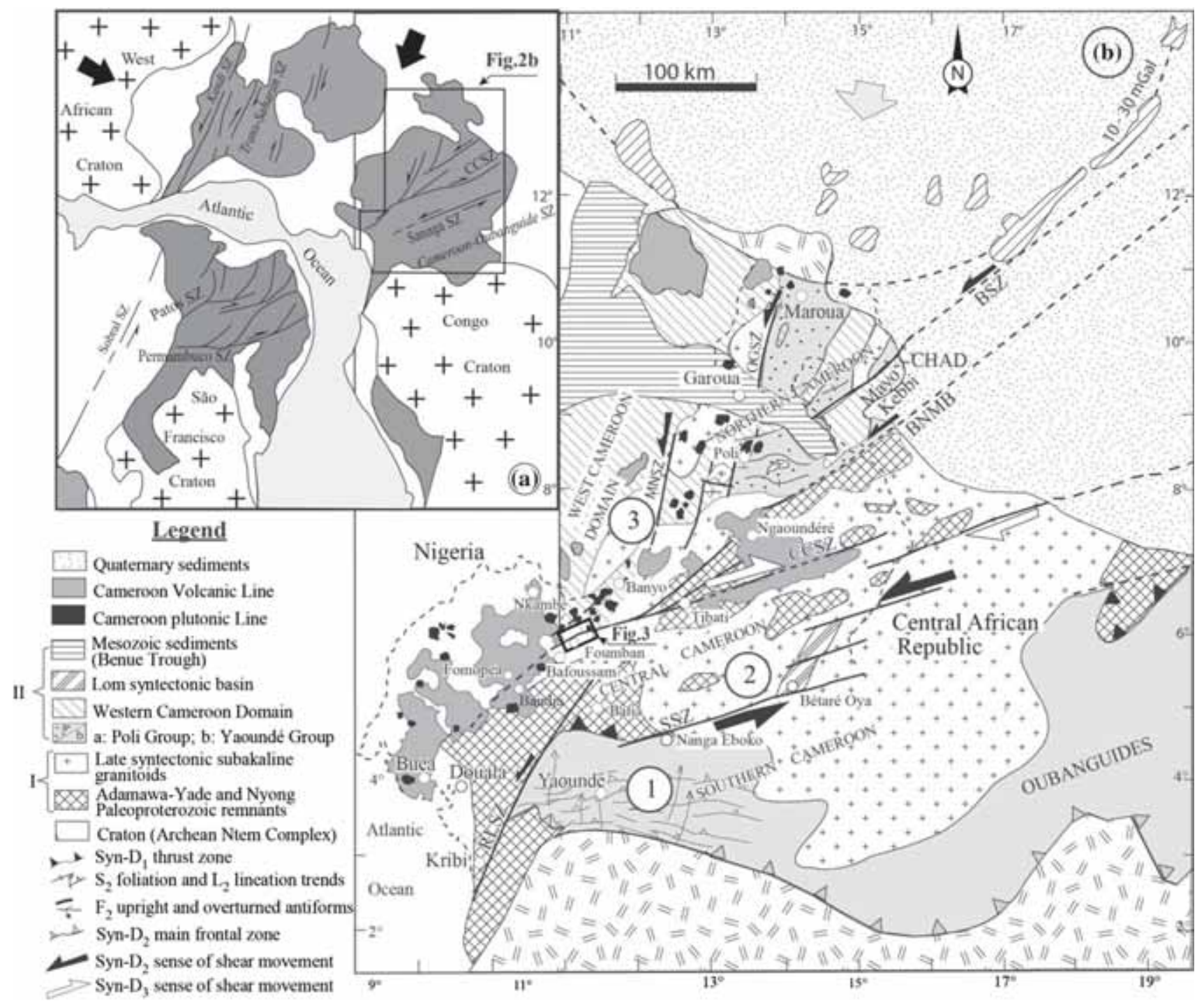

Figure 2. (a) Pan-African shear zone network in a pre-Mesozoic reconstruction (modified by Caby et al. 1991 ). SZ = shear zone. (b) Pan-African structural map of Cameroon (Ngako et al. 2008; modified and re-interpreted from Toteu et al. 2001). Large grey arrows represent the syn- $\mathrm{D}_{1-3}$ regional main stress direction. Thick lines = shear zone $(\mathrm{SZ})$ : BSZ = Balché $\mathrm{SZ}$; BNMB = Buffle Noir-Mayo Baléo; CCSZ = Central Cameroon SZ; GGSZ = Godé-Gormaya SZ; MNSZ = Mayo Nolti SZ; RLSZ = Rocher du Loup SZ; SSZ = Sanaga SZ. I: Paleo-proterozoic basement and Pan-African syntectonic granitoids; II: Meso- to Neo-proterozoic volcano-sedimentary basins.

Kappabridge (AGICO, Czech Republic) housed in the fabric analysis laboratory, at the Indian Institute of Technology (IIT)-Kharagpur (India). All these measurements were performed in spinner mode of Kappabridge and data were processed using the program Anisoft (Ver. 4.2; AGICO, Czech Republic) in order to calculate mean values of the various AMS parameters $\left(K_{\mathrm{m}}, P_{\mathrm{j}}\right.$ and $\left.T_{\mathrm{j}}\right)$ as mentioned above.

According to Mainprice et al. (1986) and Stipp et al. (2002), quartz CPO measurements help (i) to determine the mineral slip system and the sense of the shear movement and (ii) to interpret the thermo-mechanical conditions of rock deformation.
Given that the samples from Bitou S-tectonites do not show apparent mineral stretching lineation, we used the $K_{1} K_{3}$ reference frame of the AMS ellipsoid as equivalent to the $X Z$ section of the strain ellipsoid for quartz CPO measurements, as recommended by Bouchez (1997), Renjith et al. (2016) and Mamtani et al. (2017). Principles of EBSD are clearly shown by Prior et al. (1999). CPO data were measured by the EBSD technique. Analyses were performed with Carl Zeiss Auriga Compact FEG-SEM fitted with a Nordlys Max $^{2}$ EBSD detector (Oxford Instruments, UK) in the Central Research Facility (CRF, IIT Kharagpur, India). EBSD patterns were collected at an accelerating 


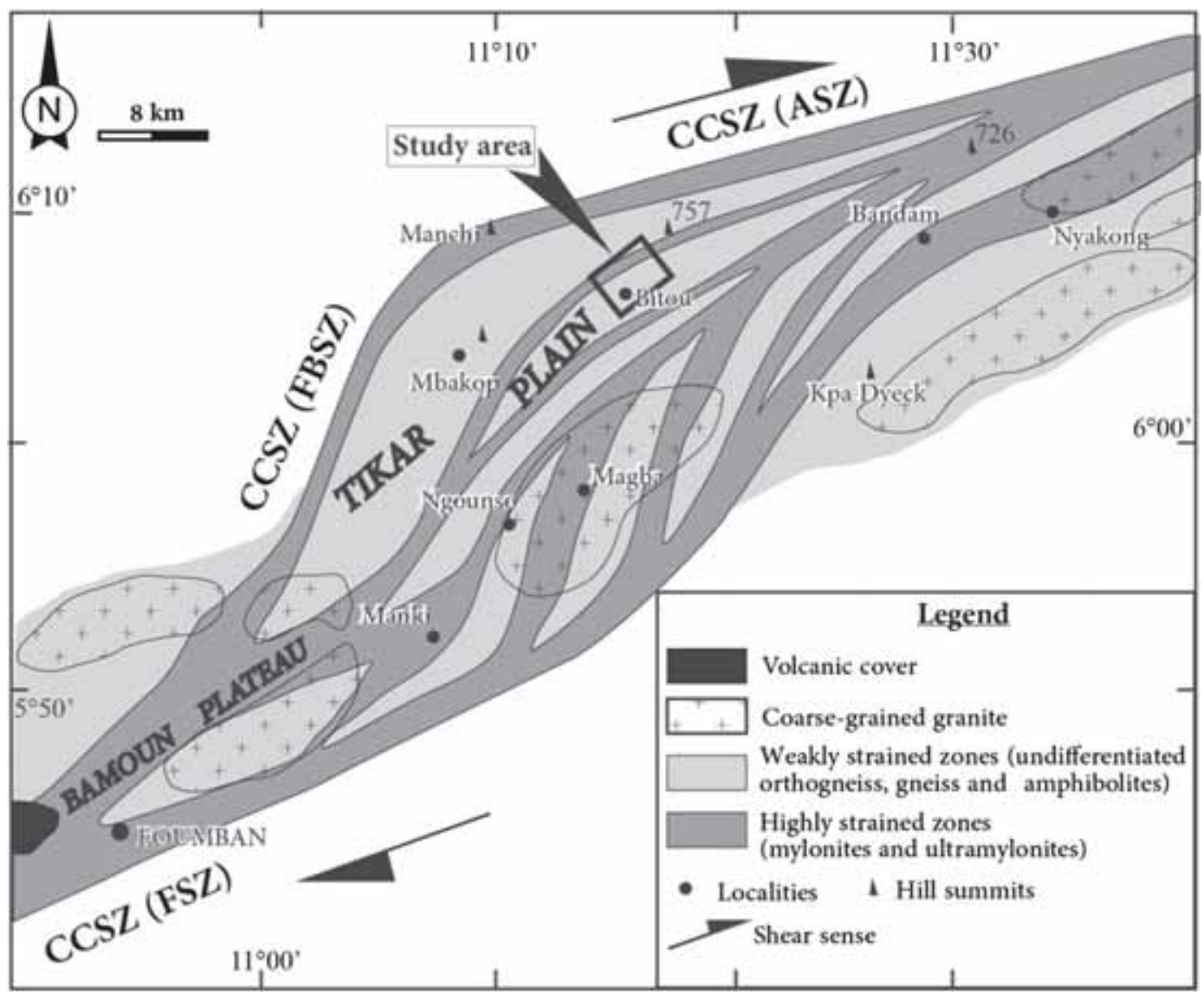

Figure 3. Geological and structural map of CCSZ in the Tikar plain after Njonfang et al. (2008). CCSZ: Central Cameroon shear zone; ASZ: Adamawa shear zone and FSZ: Foumban shear zone.

voltage of $25 \mathrm{kV}$, a system vacuum of $1.49 \times 10^{-6}$ mbar and a working distance of about $14 \mathrm{~mm}$. Acquisition data (step size at $10 \mu \mathrm{m}$ and about six frames per slide were mapped) and indexing of EBSD patterns were carried out automatically using Aztec software. Acquired data were processed using HKL that involved in the preparation of inverse pole figure maps and pole figure (lower hemisphere equal area diagram). These pole figures were plotted as one point per grains.

\section{Results}

\subsection{Petrography and structural data}

The Bitou area is made of biotite gneiss mylonite. The rock crops out as flagstone and comprises K-feldspar porphyroclasts within a fine-grained matrix composed of K-feldspar, plagioclase, quartz, biotite and titanite (figure $4 \mathrm{a}$ and $\mathrm{b}$ ). Mylonitised dark rocks are observed as forms of stretched enclaves within the host biotite gneiss mylonite.

The studied rock shows mylonitic foliation (figure 4c) that strikes ENE-WSW with low to moderate dips $\left(17^{\circ}-53^{\circ}\right)$ towards SSE with best poles at $153^{\circ} / 37^{\circ}\left(\mathrm{N} 63^{\circ} \mathrm{E} / 53^{\circ} \mathrm{NW}\right), 345^{\circ} / 52^{\circ}$ $\left(\mathrm{N} 75^{\circ} \mathrm{E} / 38^{\circ} \mathrm{E}\right), 326^{\circ} / 53^{\circ}\left(\mathrm{N} 56^{\circ} \mathrm{E} / 37^{\circ} \mathrm{SE}\right), 350^{\circ} / 73^{\circ}$ $\left(\mathrm{N} 80^{\circ} \mathrm{E} / 17^{\circ} \mathrm{SSE}\right)$ and $313 / 43^{\circ}\left(\mathrm{N} 43^{\circ} \mathrm{E} / 47^{\circ} \mathrm{SSE}\right)$ respectively for sites $\mathrm{Bi} 01, \mathrm{Bi} 02, \mathrm{Bi} 07, \mathrm{Bi} 08^{\prime}$ and Bi09 (figure 5). The mean foliation of the Bitou area (figure 5) is at $325^{\circ} / 52^{\circ}\left(\mathrm{N} 55^{\circ} \mathrm{E} / 38^{\circ} \mathrm{SE}\right)$. Kinematic markers are represented by $\sigma$-type porphyroclasts and isoclinal folds (figure 4c-f) sometimes associated with shear planes (figure $4 \mathrm{~g}$ and $\mathrm{h}$ ). $\sigma$-Type porphyroclasts indicate apparent sinistral and dextral senses of shear movement respectively towards the west and east. In previous studies, Njonfang et al. (2008) described opposite shear sense indicators overlapping shear zones within the Tikar plain mylonites. These authors concluded that this could be attributed to strain partitioning during flattening deformation as suggested by Ghosh et al. (2004) for the Achankovil shear zone in southern India. Isoclinal folds indicate apparent sinistral sense of shear movement with vergence towards SW. The fold axes display a NE-SW trend with low to moderate plunges towards southwest $\left(243^{\circ} / 53^{\circ}\right.$ 

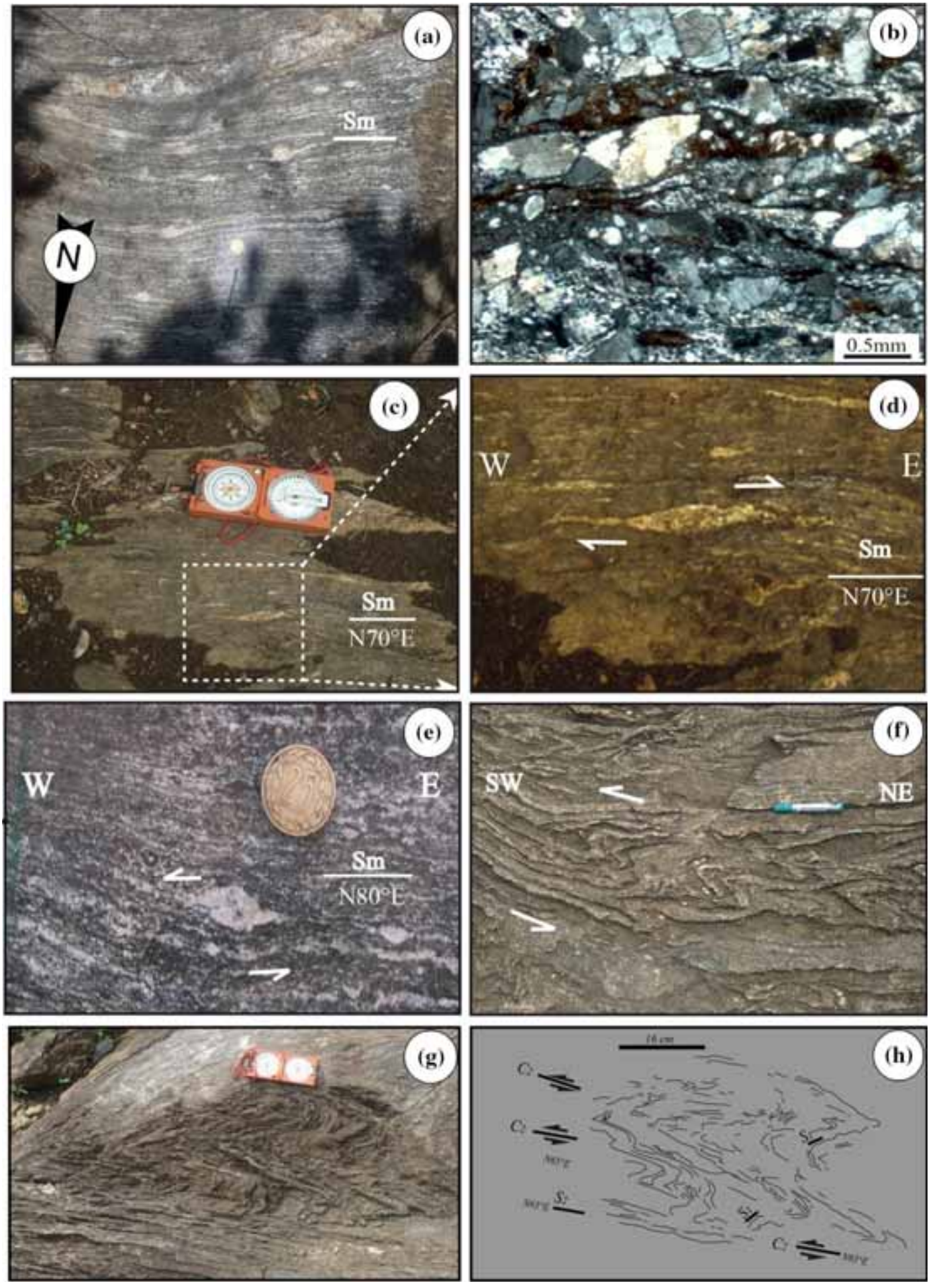

Figure 4. Field and plane photomicrograph observations of structural elements in the Bitou biotite gneiss mylonite: (a) Studied outcrop photograph; (b) (XZ) observation plane photomicrograph (under plane-polarised light) of biotite gneiss mylonite. Note abundant K-feldspar porphyroclasts and the dynamic recrystallisation of quartz grains. (c) Mylonitic foliation; (d and e) $\sigma$-type porphyroclasts indicating apparent dextral (d) and sinistral (e) senses of shear movement; (f-h) folded foliation associated with the shear plane indicating apparent sinistral sense of shear movement. Sm materialises the mylonitic foliation. Field photographs are close to $X Z$ sections.

$\left(\mathrm{N} 63^{\circ} \mathrm{E} / 53^{\circ} \mathrm{SW}\right)$ and $227^{\circ} / 08^{\circ}\left(\mathrm{N} 47^{\circ} \mathrm{E} / 08^{\circ} \mathrm{SW}\right)$ respectively for sites $\mathrm{Bi} 01$ and $\mathrm{Bi} 02)$ with the best fold axis at $233^{\circ} / 31^{\circ}\left(\mathrm{N} 53^{\circ} \mathrm{E} / 31^{\circ} \mathrm{SW}\right)$. The non-appearance of mineral stretching lineation in this biotite gneiss mylonite leads us to categorise it as an S-tectonite. Consequently, it is not 


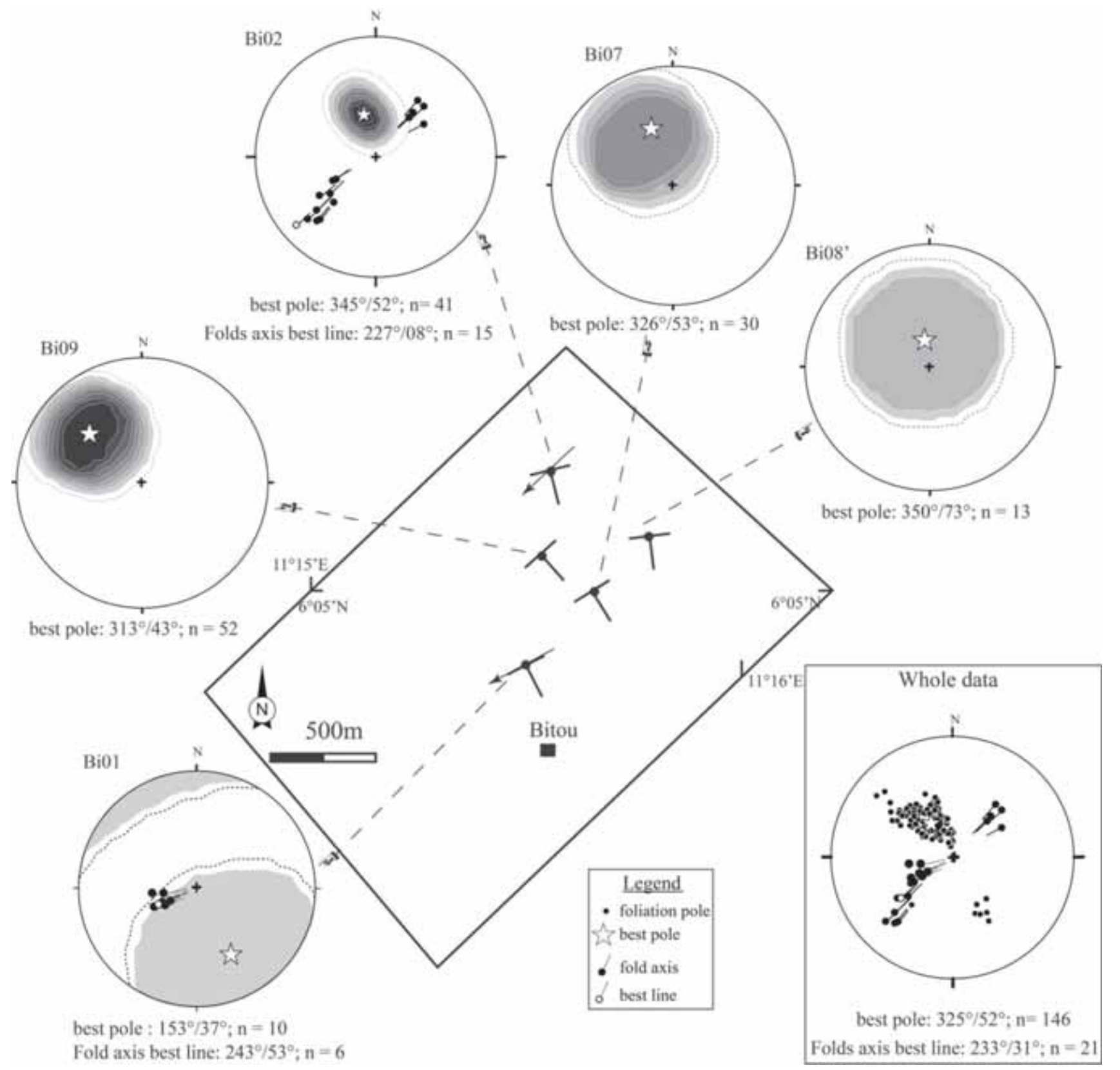

Figure 5. Structural map (foliation and fold axes) with lower hemisphere projection diagrams of the Bitou area.

possible to identify the real $X$-direction of the strain ellipsoid in the field. AMS data are therefore used for the determination of the $X Z$ section of the strain ellipsoid.

\subsection{AMS results}

AMS data from eight samples from Bitou biotite gneiss mylonite are presented in table 1 . The magnitude of the magnetic susceptibility $\left(K_{\mathrm{m}}\right.$ in $\mu \mathrm{SI}$ units) ranges from 116 to $171 \mu \mathrm{SI}$. All stations then show paramagnetic behaviour (figure 6). Rochette (1987) ranges rocks with $K_{\mathrm{m}}$ values less than $500 \mu \mathrm{SI}$ in the paramagnetic rock group, which are dominated by the signal of iron-bearing silicates such as biotite. The degree of magnetic anisotropy $\left(P_{\mathrm{j}}\right)$ varies from 1.05 to 1.13 . According to Rochette et al. (1992) and Bouchez (1997), the values of $P_{\mathrm{j}} \leq 1.15$ correspond to magnetite-free rocks. Most samples ( $87 \%$ of the stations) show an oblate shaped ellipsoid ( $T_{\mathrm{j}}>0$; figure $7 \mathrm{a}$ and $\left.\mathrm{b}\right)$. In the Flinn diagram (figure $7 \mathrm{c}$ ), most samples plot in the flattening domain.

Magnetic foliations (perpendicular to $K_{3}$ ) are steeply dipping with ESE-WNW strike and the best pole at $197^{\circ} / 13^{\circ}\left(\mathrm{N} 107^{\circ} \mathrm{E} / 77^{\circ} \mathrm{S}\right.$ ) (figure $8 \mathrm{a}$ ). 
Table 1. Summary of magnetic scalar $\left(K_{m}, P_{j}\right.$ and $\left.T_{j}\right)$ and directional data $\left(K_{1}\right.$ and $\left.K_{3}\right)$ of the Bitou biotite gneiss mylonite.

\begin{tabular}{|c|c|c|c|c|c|c|c|c|c|}
\hline \multirow[b]{3}{*}{$\underline{\text { Sites }}$} & \multirow{3}{*}{$\begin{array}{c}K_{\mathrm{m}} \\
(\mu \mathrm{SI})\end{array}$} & \multirow[b]{3}{*}{$F$} & \multicolumn{3}{|c|}{ Mean AMS parameters } & \multicolumn{4}{|c|}{ Mean eigenvectors } \\
\hline & & & \multirow[b]{2}{*}{$L$} & \multirow[b]{2}{*}{$P_{\mathrm{j}}$} & \multirow[b]{2}{*}{$T_{\mathrm{j}}$} & \multicolumn{2}{|c|}{$K_{1}$} & \multicolumn{2}{|c|}{$K_{3}$} \\
\hline & & & & & & $\operatorname{Dec}\left({ }^{\circ}\right)$ & $\operatorname{Inc}\left(^{\circ}\right)$ & $\operatorname{Dec}\left(^{\circ}\right)$ & $\operatorname{Inc}\left({ }^{\circ}\right)$ \\
\hline $\mathrm{Bi01}$ & 135 & 1.06 & 1.04 & 1.09 & 0.21 & 203 & 42 & 342 & 40 \\
\hline $\mathrm{Bi02}$ & 116 & 1.08 & 1.02 & 1.11 & 0.58 & 260 & 42 & 352 & 11 \\
\hline $\mathrm{Bi03}$ & 131 & 1.07 & 1.04 & 1.12 & 0.34 & 64 & 67 & 226 & 25 \\
\hline $\mathrm{Bi04}$ & 123 & 1.02 & 1.02 & 1.05 & 0.07 & 32 & 45 & 249 & 40 \\
\hline $\mathrm{Bi05}$ & 137 & 1.03 & 1.04 & 1.07 & -0.07 & 205 & 72 & 41 & 10 \\
\hline $\mathrm{Bi06}$ & 141 & 1.07 & 1.01 & 1.09 & 0.78 & 331 & 40 & 221 & 17 \\
\hline $\mathrm{Bi} 07$ & 171 & 1.09 & 1.02 & 1.11 & 0.68 & 241 & 70 & 170 & 18 \\
\hline $\mathrm{Bi08}$ & 143 & 1.07 & 1.05 & 1.13 & 0.16 & 285 & 13 & 185 & 37 \\
\hline
\end{tabular}

$K_{1}$ and $K_{3}$ are the maximum and minimum susceptibility intensities, respectively; $K_{\mathrm{m}}=\left(K_{1-}\right.$ $\left.+K_{2}+K_{3}\right) / 3$ is the mean magnetic susceptibility; $P_{\mathrm{j}}=\exp \sqrt{\left(2\left(\eta_{1}-\eta_{m}\right)^{2}+\left(\eta_{2}-\eta_{m}\right)^{2}\left(\eta_{3}-\eta_{m}\right)^{2}\right.}$ with $\eta_{\mathrm{i}}=\ln K_{\mathrm{i}}$ and $\eta_{\mathrm{m}}=\left(\eta_{1}-\eta_{2}-\eta_{3}\right)^{1 / 3}$, is the corrected degree of magnetic anisotropy; $T_{\mathrm{j}}=(2$ $\left.\ln \left(K_{2} / K_{3}\right) /\left(\ln \left(K_{1} / K_{3}\right)\right)-1\right)$ is the shape parameter (Jelinek 1981); Inc: Inclinaison; Dec: Declinaison.

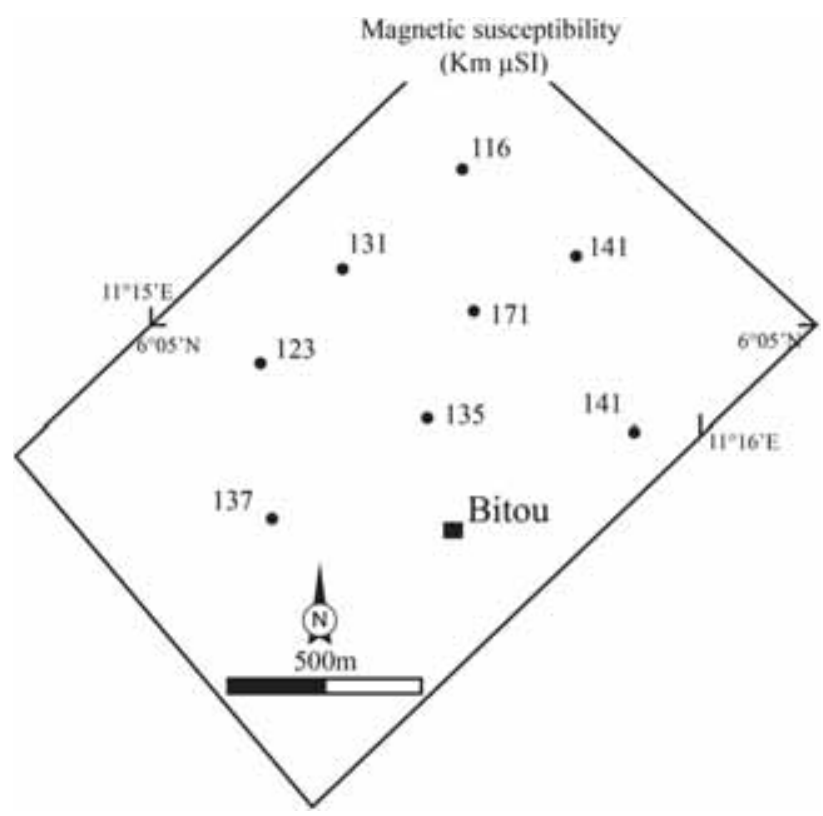

Figure 6. Magnetic susceptibility $\left(K_{\mathrm{m}}\right)$ map in $\mu$ SI of the Bitou biotite gneiss mylonite.

The magnetic lineation $\left(K_{1}\right)$ shows moderate to high plunges towards southwest and west (figure $8 \mathrm{~b}$ ). The main orientation is $272^{\circ} / 71^{\circ}$ $\left(\mathrm{N} 92^{\circ} \mathrm{E} / 71^{\circ} \mathrm{W}\right)$.

Biotite gneiss mylonite is mostly made of biotite, K-feldspar, plagioclase and quartz and the $P_{\mathrm{j}}$ value is not more than 1.15. Petrographic evidence and the low values of $K_{\mathrm{m}}(<500 \mu \mathrm{SI})$ of the study rock imply that the AMS is controlled by paramagnetic minerals such as biotite. The $K_{1}, K_{2}$ and $K_{3}$ orientations indicate the preferred orientation of minerals, due to the deformation, in the rock. Thus, the orientation of AMS ellipsoid principal axes $K_{1} \geq K_{2} \geq K_{3}$ can be correlated with those of the strain ellipsoid, respectively $X \geq Y \geq Z$.

\subsection{Microstructures, kinematic markers and $C P O$ data}

Microstructures and kinematic markers were studied on oriented thin sections prepared parallel to the $K_{1}$ axis of the AMS ellipsoid (known as magnetic lineation) and perpendicular to the magnetic foliation $\left(K_{1} K_{2}\right)$ plane. The microstructure is mostly defined by dynamic recrystallisation of quartz grains indicating dominance of the subgrain rotation (SGR, figure 9). Kinematic markers are (i) bookshelf structures (Etchecopar 1977; Samanta et al. 2002) (figure 9a) illustrated by antithetic microfaults transecting K-feldspar porphyroclasts with fragments oblique to the NE-SW main shear direction; (ii) quartz grains developed obliquely to the shear direction (figure 8b) and (iii) asymmetric $C$-axis of quartz grains (figure 10). The interpretation of all these kinematic indicators points to sinistral sense of shear movement towards-SW which, in the geographical reference frame, corresponds to top-to- $212^{\circ},-226^{\circ}$ and $-285^{\circ}$, respectively.

$\mathrm{CPO}$ analysis on quartz grains is presented in figure 10. The quartz CPO is characterised by girdle along a plane that passes through the $K_{2}$ 


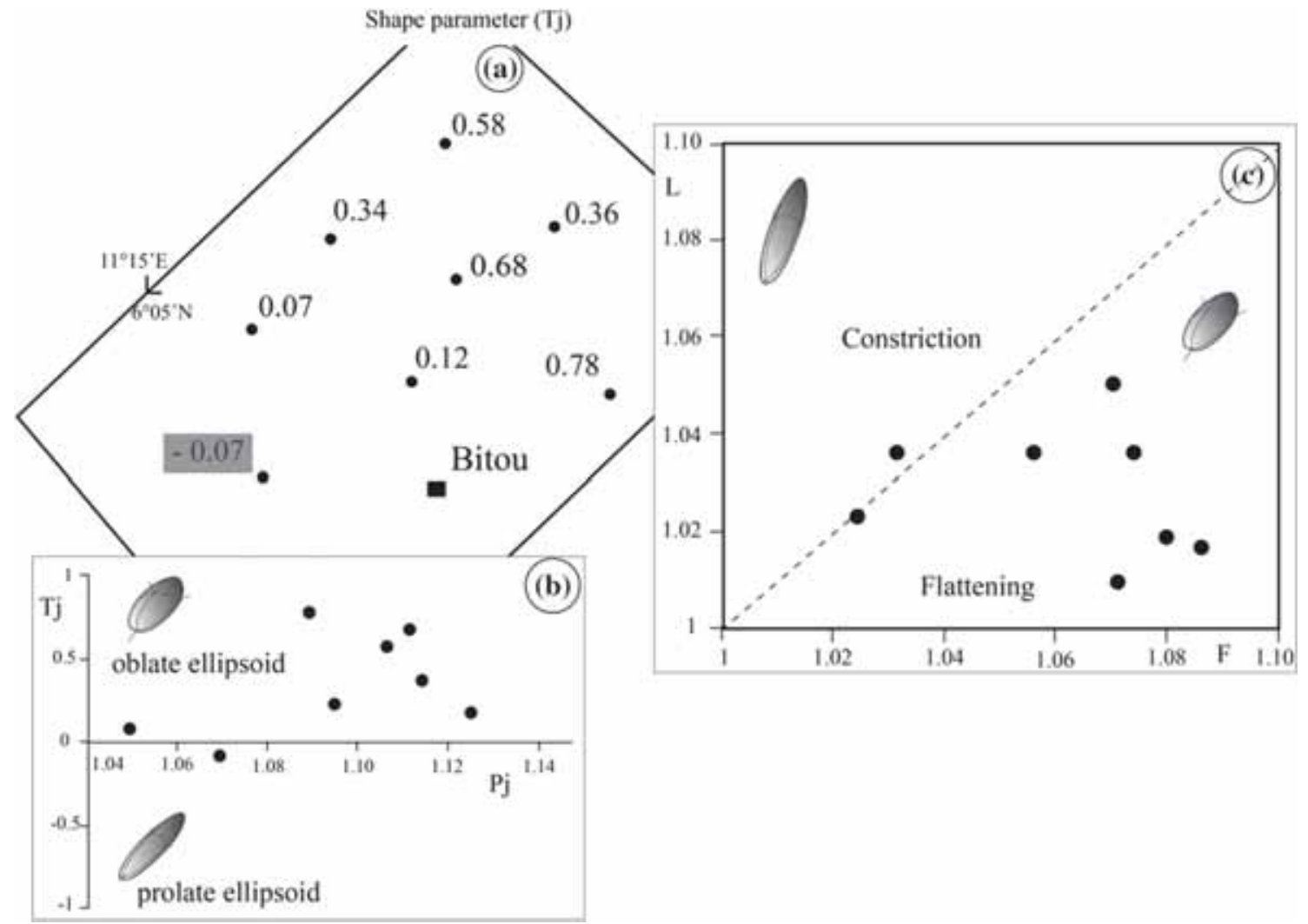

Figure 7. Jelinek shape parameter $\left(T_{\mathrm{j}}\right)$ map: $(\mathbf{a})$ with the Jelinek shape parameter $\left(T_{\mathrm{j}}\right)$ vs. degree of magnetic anisotropy $\left(P_{\mathrm{j}}\right)$; (b) and planar anisotropy $(F)$ vs. linear anisotropy $(L)$ plot; $(\mathbf{c})$ of the Bitou biotite gneiss mylonite. Note most samples are of oblate shaped ellipsoid and they plot within the flattening domain of the Flinn diagram (c).

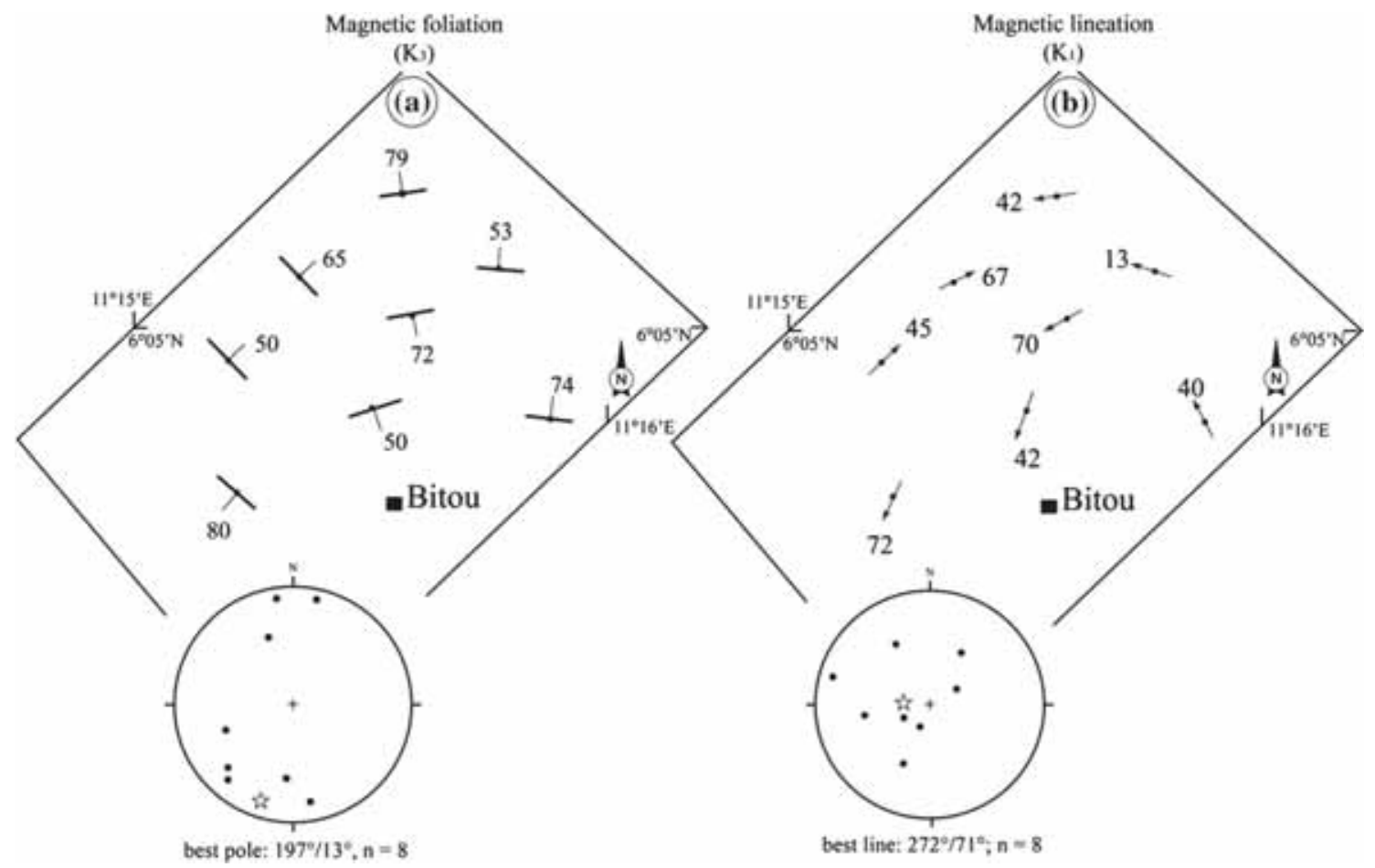

Figure 8. Magnetic fabric maps of the Bitou area: Magnetic foliation (a) and magnetic lineation (b) with lower hemisphere projection diagrams. 

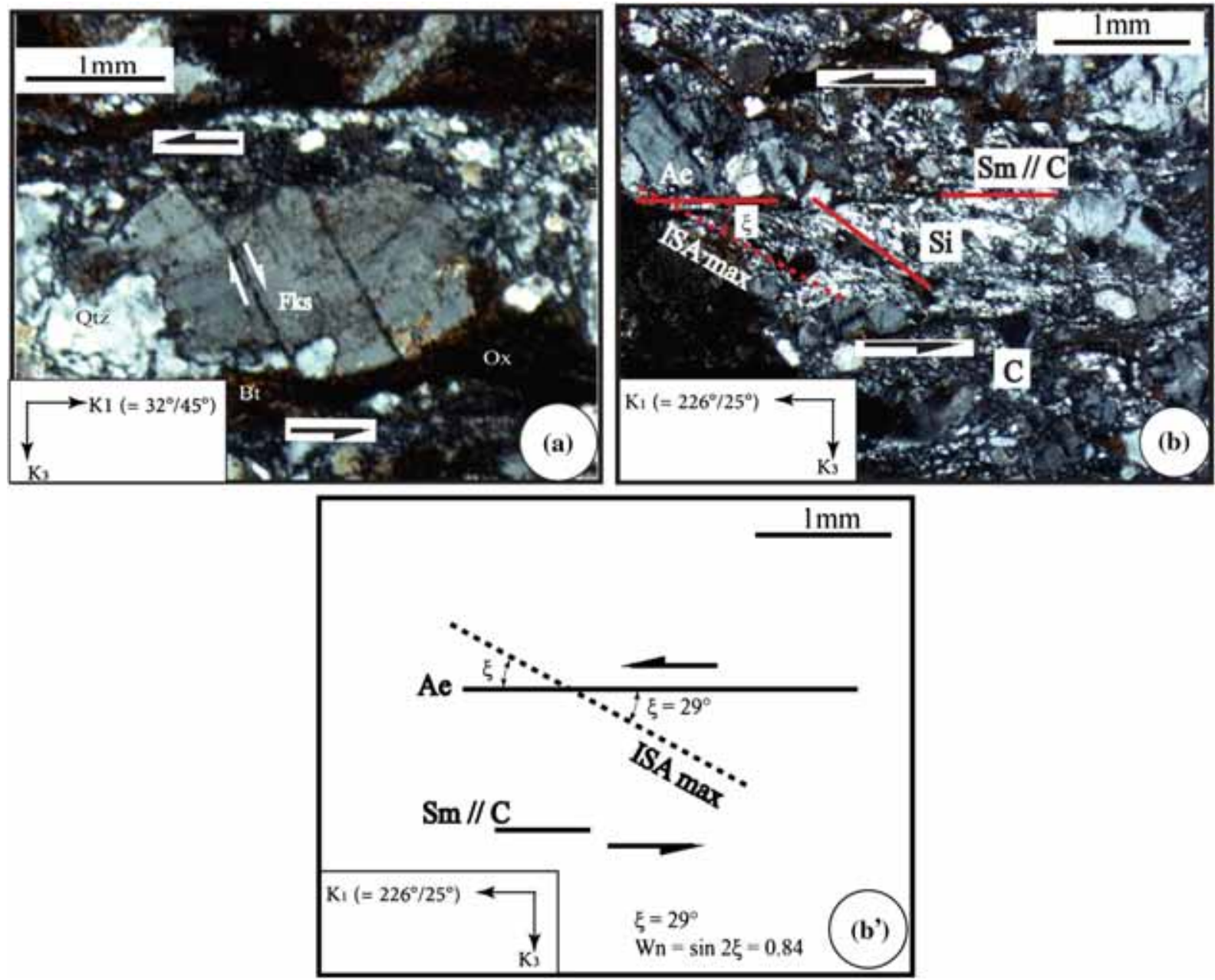

Figure 9. Photomicrographs (the $K_{1} K_{3}$ plane) of microstructures and kinematic markers: (a) K-feldspar antithetic microfractures; note the sinistral sense of the mean shear towards southwest and the dextral sense of the shear movement along the K-feldspar microfractures. (b) Quartz grains developed obliquely to the shear plane, indicating sinistral shear movement. Note in the both photomicrographs, the dynamic recrystallisation of quartz grains. (b') Calculated kinematic vorticity number (Wn) using the oblique foliation defined by quartz (ISA max) and the shear plane (Ae) based on (b) the photomicrograph. Wn = sin $2 \xi=0.84$.

axis. The maximum concentration of $\{0001\}$ axis is clearly defined close to $K_{2}$, indicating intracrystalline deformation of quartz by prism <a> slip, where the maximum quartz $c$-axis occupies the centre of the pole figure.

\section{Discussion and conclusion}

The Bitou biotite gneiss mylonite, which is part of the northeastern segment of the Tikar plain, developed field and magnetic fabrics that strike ENE-WSW to E-W. Foliations (mylonitic and magnetic) display moderate to steep dips towards $\mathrm{SE}, \mathrm{SW}, \mathrm{N}$ to NNE and NE. The magnetic lineation displays gentle plunges towards SW (four stations over eight), NE (two stations), WSW to
WNW and NNW with the best line plunging towards W $\left(272^{\circ} / 71^{\circ}\right.$; figure $\left.8 \mathrm{~b}\right)$. Moderate to steeply dipping mylonitic and magnetic foliations with gently plunging magnetic lineation imply that extension was important during the last deformation event. Magnetic fabrics from AMS data of the studied rock are subparallel to the mesoscopic foliation, implying, according to Ono et al. (2010), that the magnetic fabric 'mimics' the foliation developed during the late stage of progressive deformation.

The fabrics are associated with sinistral and dextral senses of shear movement as recorded by (i) asymmetric K-feldspar porphyroclasts which indicate apparent dextral sense of shear movement, (ii) antithetic microfaults transecting K-feldspar porphyroclasts with fragments showing 


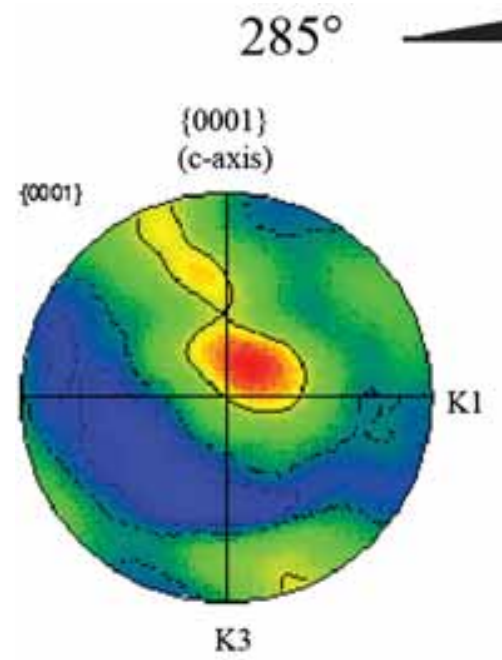

(a)

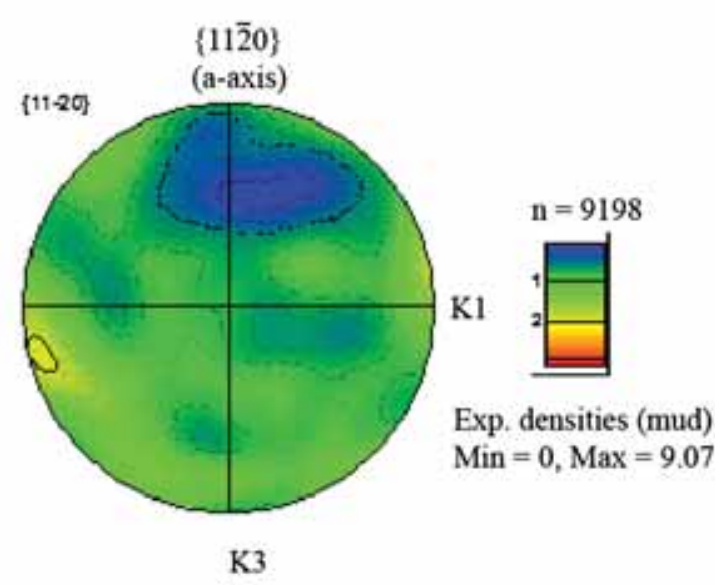

(b)

Figure 10. Quartz CPO data acquired through SEM-EBSD analysis of the sample Bi08 thin section from the Bitou biotite gneiss mylonite. Bi08: $K_{\mathrm{m}}, P_{\mathrm{j}}$ and $T_{\mathrm{j}}$ values are respectively $143 \mu \mathrm{SI}$ units, 1.13 and 0.16 . The pole figures plotted are in lower hemisphere, equal area, one point per grain of $\{0001\}$, i.e., $c$-axis, and $\{1120\}$, i.e., $a$-axis of the quartz grains. The sense of shear inferred from quartz CPO is top-towards- $285^{\circ}$ (the direction of $K_{1}$ ); $n$ indicates the number of quartz grains.

sinistral sense of shear movement towards-southwest, (iii) the development of quartz grains oblique to the shear direction, and (iv) the asymmetric $c$-axis of quartz grain patterns. These sinistral and dextral (mostly represented) senses of shear movements described in the Bitou area are similar to the syn- $\mathrm{D}_{2}$ and syn- $\mathrm{D}_{3}$ events described in the CCSZ by (i) Njonfang et al. (2006, 2008), Ngako and Njonfang (2011) and Bella Nké et al. (2018) in its vicinity and (ii) Njanko et al. (2010) and Tcheumenak Kouémo et al. (2014) in its southwestern part. Porphyroclast systems with opposite shear senses might occur, according to Hanmer (1982), during strikeslip shearing by a passive slip of previous foliation related to a component of coaxial deformation and consistent with transpression where pure shear prevailed as the most important tectonic regime (Egydio-Sylva and Mainprice 1999). According to Njonfang et al. (2008), reverse shear sense indicators (as described in the Bitou biotite gneiss mylonite) are indicative of multi-stage mylonitisation, compatible with successive shearing events that were also described by Ngako et al. (2003) in the western Tibati area situated at about $60 \mathrm{~km}$ east of the study area. The syn- $\mathrm{D}_{2}$ to $\mathrm{D}_{3}$ evolution of the Bitou area implies that the fabrics developed in the studied biotite gneiss mylonite begun from the earlier sinistral syn- $\mathrm{D}_{2}$ event and evolved during the entire major dextral $\mathrm{D}_{3}$ event of the
Pan-African through a transpressive deformation mechanism. This statement supports the hypothesis of two senses of shear movement in the same direction within the CCSZ (Njonfang et al. 2008). The fabric orientation, coupled with the sinistral and dextral senses of shear movement recorded in the Bitou biotite gneiss mylonite is compatible respectively with the N-S to NW-SE main stress directions of the Pan-African tectonic emphasised by Ngako et al. (2008).

Quartz $c$-axis patterns are typical of non-coaxial flow (figure 10) and the ellipsoid of AMS is mostly oblate (figure 7). The cohabitation of both flow mechanisms within the samples implies that deformation was partitioning during mylonitisation, inferring that, it would not be possible to emphasise such deformation partitioning within the Bitou area without AMS data.

The flow mechanism in the Bitou biotite gneiss mylonite has been quantified by calculating the kinematic vorticity number (Wn; Wallis 1995; Xypolias 2010; Mamtani 2014). On the microphotograph (figure 10b), the angle $\xi$ between the oblique foliation defined by stretched-quartz grains (ISAmax) and the shear plane parallel to the extensional flow apophysis (Ae) is equal to $29^{\circ}$ (figure 10c). Hence, $\mathrm{Wn}=\sin 2 \xi=0.84$. This result infers that the flow mechanism in the study area was close to simple shear as supported by other mesoscopic kinematic markers and asymmetry of quartz $c$-axes. 
The CPO data indicates that the mylonitisation occurs under moderate temperature conditions $\left(T>500^{\circ} \mathrm{C}\right)$. Moreover, according to Okudaira et al. (1995), the $K_{2}$ maximum $C$-axis (indicative of prism $<$ a $>$ slip) starts to develop at $450^{\circ} \mathrm{C}$ and the dynamic recrystallisation of quartz grains by SGR occurs between $400^{\circ}$ and $500^{\circ} \mathrm{C}$ (Stipp et al. 2002). The deformation was due to the activation of prism $<$ a $>$ slip (Passchier and Trouw 2005). Thus, prism $<$ a $>$ slip in biotite gneiss mylonite samples indicates that deformation occurs at moderate temperature $\left(450^{\circ} \mathrm{C}<T<550^{\circ} \mathrm{C}\right)$.

Kinematic analysis on foliated-deformed rocks that do not develop mineral stretching lineation such as S-tectonites, requires systematic investigation of structures, microstructures and sense of shear in the $X Z$ section of the strain ellipsoid that indicates the $X$-direction of the strain ellipsoid. In such rocks, AMS is very useful in the fabric analysis and CPO data of quartz $c$-axis can help to determine (i) the sense of shear movement and (ii) the temperature of deformation. The application of these methods on the Bitou biotite gneiss mylonite reveals:

- a paramagnetic rock that recorded microstructures which indicate sinistral and dextral senses of shear movement (respectively towards-west or southwest and -east) induced by a continuous deformation during simple shear. However, giving the predominance of the oblate shaped AMS ellipsoid, this deformation is likely associated with a coaxial deformation component;

- Quartz CPO showing (i) prism <a> slip activation indicating that the deformation occurs under moderate temperature and (ii) quartz $c$-axis indicating sinistral sense of shear top-to- $285^{\circ}$.

These results are consistent with the sinistral syn- $\mathrm{D}_{2}$ and dextral $\mathrm{D}_{3}$ events evolved during the Pan-African tectonics through a transpressive deformation mechanism recorded in the CAFB.

\section{Acknowledgements}

This paper is a part of Ph.D. research works carried out by B E Bella Nké. The first author is grateful to the Organisation for Women in Science for the Developing World (OWSD) and Swedish International Development Cooperation Agency (Sida) for the fellowship (Grant No. 3240280840) that enabled her to acquire data (AMS and EBSD) at IIT Kharagpur (India). Special thanks to Niloy Bhowmik for his technical support during the EBSD analysis at the Central Research Facility (CRF, IIT Kharagpur, India).

\section{References}

Bella Nké B E, Njanko T, Mamtani M A, Njonfang E and Rochette P 2018 Kinematic evolution of the Mbakop PanAfrican granitoids (western Cameroon domain): An integrated AMS and EBSD approach; J. Struct. Geol. 111 42-63.

Bikramaditya Singh R K, Krishnakanta Singh A, Sen K and Sangode S J 2017 Detection of a weak late-stage deformation event in granitic gneiss through anisotropy of magnetic susceptibility: Implications for tectonic evolution of the Bomdila Gneiss in the Arunachal Lesser Himalaya, Northeast India; Geol. Mag. 154(3) 476-490.

Borradaile G J 1988 Magnetic susceptibility, petrofabric and strain; Tectonophys. 156 1-20.

Borradaile G J and Jackson M 2004 Anisotropy of magnetic susceptibility (AMS): Magnetic petrofabrics of deformed rocks; In: Magnetic fabric: Methods and applications (eds) Martín-Hernández F, Lüneburg C M, Aubourg C and Jackson M, Geol. Soc. London, Spec. Publ. 238 299-360.

Bouchez J L 1997 Granite is never isotropic: An introduction to AMS studies of granitic rocks; In: Granite: From Segregation of Melt to Emplacement Fabrics (eds) Bouchez J L, Hutton D W H and Stephens W E, Kluwer Academic Publishers, Dordrecht, pp. 95-112.

Brito Neves B B, Van Schmus W R, Fetter A 2002 Northwestern Africa-North-eastern Brazil: major tectonic links and correlation problems. J. Afr. Earth Sci. 34 275-278.

Caby R, Sial A N, Arthaud M and Vauchez A 1991 Crustal evolution and the Braziliano orogeny in northeast Brazil; In: The West African Orogens and Circum-Atlantic Correlatives (eds) Dallmeyer R D, Lecorche J C P L, Springer, Berlin, pp. 373-397.

Canon-Tapia E 1994 AMS parameters: Guidelines for their rational selection; Pure Appl. Geophys. 142 365-382.

Cordani U G, D'Agrella-Filho M S, Brito-Neves B B, Trindade R I F 2003 Tearing up Rodinia: the Neoproterozoic palaeogeography of South American cratonic fragments. Terra Nova 15 350-359.

Egydio-Sylva M and Mainprice D 1999 Determination of stress directions from plagioclase fabrics in high grade deformed rocks (Além Paraiba shear zone, Ribeira fold belt, southeastern Brazil). J. Struct. Geol. 21 1751-1771.

Etchecopar A 1977 A plane kinematic model of progressive deformation in a polycrystalline aggregate; Tectonophys. 39 121-139.

Ghosh J G, de Wit M J, Zartman R E 2004 Age and tectonic evolution of Neoproterozoic ductile shear zone in the southern Granulite Terrain of India, with implications for Gondwana studies. Tectonics 23 https://doi.org/10.1029/ 2002 TC001444.

Goswami S, Mamtani M A and Virendra R 2018 Quartz CPO and kinematic analysis in deformed rocks devoid of visible stretching lineations: An integrated AMS and EBSD 
investigation; J. Struct. Geol. https://doi.org/10.1016/j. jsg.2018.04.008.

Hanmer S 1982 Microstructure and geochemistry of plagioclase and microcline in naturally deformed granite. $J$. Struct. Geol. 4 197-213.

Hanmer S and Passchier C W 1991 Shear sense indicators: a review. Geol. Surv. Can. 90 1-71.

Hrouda F 1982 Magnetic anisotropy of rocks and its application in geology and geophysics; Geophys. Surv. 5 37-82.

Jelinek V 1981 Characterization of the magnetic fabric of rocks. Tectonophys. $\mathbf{7 9}, 563-567$.

Mamtani M A 2014 Magnetic fabric as a vorticity gauge in syn-tectonically deformed granitic rocks; Tectonophys. 629 189-196.

Mamtani M A and Greiling R O 2005 Granite emplacement and its relation with regional deformation in the Aravalli Mountain Belt (India)-Inferences from magnetic fabric; $J$. Struct. Geol. 27 2008-2029.

Mamtani M A and Sengupta P 2010 Significance of AMS analysis in evaluating superposed folds in quartzites; Geol. Mag. 147 910-918.

Mamtani M A, Greiling R O, Karanth R V and Merh S S 1999 Orogenic deformation and its relationship to AMS fabric-An example from the southern margin of the Aravalli Mountain Belt, India; In: The Indian subcontinent and Gondwana: A palaeomagnetic and rock magnetic perspective (eds) Radhakrishna T and Piper J D A, Geol. Soc. India Memoir 44 9-24.

Mamtani A M, Abhijith V, Lahiri S, Rana V, Bhatt S, Goswami S and Renjith A R 2017 Determining the reference frame for kinematic analysis in S-tectonites using AMS; J. Geol. Soc. India 90 5-8.

Mainprice D, Bouchez J L, Blumenfeld E and Tubih J M 1986 Dominant c-slip in naturally deformed quartz: Implications for dramatic plastic softening at high temperature; Geology 14 819-822.

Mondou M, Edgydio-Silva M, Vauchez A, Raposo M I B, Bruguier O and Oliverira A F 2012 Complex, 3D strain patterns in a synkinematic tonalite batholith from the Aracuaí Neoproterozoic orogen (Eastern Brazil): Evidence from combined magnetic and isotopic chronology studies; $J$. Struct. Geol. 39 158-179.

Ngako V and Njonfang E 2011 Plates amalgamation and plate destruction, the Western Gondwana history; Tectonics INTECH, London, 34p.

Ngako V, Affaton P, Nnange J M and Njanko T 2003 PanAfrican tectonic evolution in central and southern Cameroon: Transpression and transtension during sinistral shear movements; J. Afr. Earth Sci. 36 207-214.

Ngako V, Affaton P and Njonfang E 2008 Pan-African tectonics in northwestern Cameroon: Implication for the history of Western Gondwana; Gondwana Res. 14 509-522.

Njanko T, Nédélec A and Affaton P 2006 Synkinematic high$\mathrm{K}$ calc-alkaline plutons associated with the Pan-African Central Cameroon shear zone (W-Tibati area): Petrology and geodynamic significance; J. Afr. Earth Sci. 44 494-510.

Njanko T, Nédélec A, Kwékam M, Siquiéra R and Estéban L 2010 Emplacement and deformation of the Fomopéa pluton: Implication for the Panafrican history of Western Cameroon; J. Struct. Geol. 32 306-320.
Njonfang E, Moreau C and Tchoua F M 1998 La bande mylonitique Foumban-Bankim, Ouest Cameroun. Une zone de cisaillement de haute température; $C R$ Acad. Sci. Paris 327 735-741.

Njonfang E, Ngako V, Kwékam M and Affaton P 2006 Les orthogneiss calco-alcalins de Foumban-Bankim: Témoins d'une zone interne de marge active panafricaine en cisaillement; CR Geosci. 338 606-616.

Njonfang E, Ngako V, Moreau C and Affaton P 2008 Restraining bends in high temperature shear zone: 'the central Cameroon'; J. Afr. Earth Sci. 52 9-20.

Okudaira T, Takeshita T, Hara I and Ando J 1995 A new estimate of the conditions for transition from basal $<\mathrm{a}>$ to prism [c] slip in naturally deformed quartz; Tectonophys. $25031-46$.

Ono T, Hosomi Y, Arai H and Takagi H 2010 Comparison of petrofabrics with composite magnetic fabrics of S-C mylonite in paramagnetic granite; J. Struct. Geol. 32 2-14.

Parsons A J, Ferré E C, Law R D, Lloyd G E, Phillips R J and Searle M P 2016 Orogen-parallel deformation of the Himalayan mid-crust: Insights from structural and magnetic fabric analyses of the greater Himalayan sequence, Annapurna-Dhaulagiri Himalaya, central Nepal; Tectonics 35 2515-2537.

Passchier C W and Trouw R A J 2005 Microtectonics; Springer, Berlin.

Prior D J, Boyle A P, Brenker F, Cheadle M C, Day A, Lopez G, Peruzzo L, Potts G J, Reddy S M, Spiess R, Trimby P W, Wheeler J and Zetterström L 1999 The application of electron backscatter diffraction and orientation contrast imaging in the SEM to textural problems in rocks; $\mathrm{Am}$. Miner. 84 1741-1759.

Raposo M I B and Gastal M C P 2009 Emplacement mechanism of the main granite pluton of the Lavras do Sul intrusive complex, South Brazil, determined by magnetic anisotropies; Tectonophys. 466 18-31.

Renjith A R, Mamtani M A and Urai J L 2016 Fabric analysis of quartzites with negative magnetic susceptibility - Does AMS provide information of SPO or CPO of quartz? J. Struct. Geol. 82 48-59.

Rochette P 1987 Magnetic susceptibility of rock matrix related to magnetic fabric studies. J. Struct. Geol. 9 1015-1020.

Rochette P, Jackson M and Aubourg C 1992 Rock magnetism and the interpretation of anisotropy of magnetic susceptibility; Rev. Geophys. 3 209-226.

Samanta S K, Mandal N and Chakraborty C 2002 Development of different types of pull-apart microstructures in mylonites: An experimental investigation; J. Struct. Geol. 24 1345-1355.

Sen K and Mamtani M A 2006 Magnetic fabric, shape preferred orientation and regional strain in granitic rocks; J. Struct. Geol. 28 1870-1882.

Stipp M, Stünitz H, Heilbronner R and Schmid S M 2002 The eastern Tonalite fault zone: A 'natural laboratory for crystal plastic deformation of quartz over a temperature range from $250^{\circ}-700^{\circ} \mathrm{C}$; J. Struct. Geol. 24 1861-1884.

Tarling D H and Hrouda F 1993 The magnetic anisotropy of rocks; Chapman and Hall, London, 217p.

Tcheumenak Kouémo J, Njanko T, Kwékam M, Naba S, Bella Nké B E, Yakeu Sandjo A F, Fozing E M and Njonfang E 2014 Kinematic evolution of the Fodjomekwet-Fotouni Shear Zone (West-Cameroon): Implications for 
emplacement of the Fomopéa and Bandja plutons; J. Afr. Earth Sci. 99 261-275.

Tomezzoli R N, McDonald W D and Tickyj H 2003 Composite magnetic fabric and S-C structures in granite gneiss of Cerro de los Viejos, La Pampa province, Argentina; J. Struct. Geol. 5 $351-368$.

Toteu S F, Van Schmus W R, Penaye J, Michard A 2001 New $\mathrm{U}-\mathrm{Pb}$ and $\mathrm{Sm}-\mathrm{Nd}$ data from north-central Cameroon and its bearing on the pre-Pan African history of central Africa. Prec. Res. 108 45-73.

Wallis S R 1995 Vorticity analysis and recognition of ductile extension in the Sanbagawa belt, SE Japan; J. Struct. Geol. 17 1077-1093.

Xypolias P 2010 Vorticity analysis in shear zones: A review of methods and applications; J. Struct. Geol. 32 20722092 .

Corresponding editor: SAIBal Gupta 